\title{
Efektivitas Pelayanan E-Commerce Shopee sebagai Upaya Menciptakan Kepuasan Konsumen Berbelanja Online
}

\author{
Vusiaria Stella Wijaya ${ }^{1 *}$, Eko Harry Susanto \\ ${ }^{1}$ Fakultas Ilmu Komunikasi Universitas Tarumanagara, Jakarta* \\ Email:vusiariastellaw@gmail.com \\ ${ }^{2}$ Fakultas Ilmu Komunikasi Universitas Tarumanagara, Jakarta \\ Email:ekos@fikom.untar.ac.id
}

Masuk tanggal : 15-12-2021, revisi tanggal :06-01-2022, diterima untuk diterbitkan tanggal : 16-01-2022

\begin{abstract}
In the field of information technology, e-commerce is one of the fastest growing platforms. ECommerce has made it easier for the public with a new shopping platform. All information needed by consumers can be easily searched and accessed in detail and quickly without being limited by place and time. This study aims to analyze whether service quality affects consumer satisfaction of Shopee e-commerce users. Customer satisfaction is an obligation for a company to be a reference for determining the company's career. What if the customer is not satisfied with the services provided, the analysis of this research uses quantitative research methods and the results of the data are calculated using SPPS. The results of this study show the effect of service quality on customer satisfaction by $66.0 \%$, and service quality has a strong relationship with customer satisfaction and is positive.
\end{abstract}

Keywords:, customer satisfaction, e-commerce, Shopee, service quality

\begin{abstract}
Abstrak
Di dalam bidang teknologi informasi, e-commerce menjadi salah satu platform yang sangat berkembang dengan pesat. E-Commerce telah memudahkan masyarakan dengan platform belanja baru. Semua informasi yang dibutuhkan oleh konsumen dapat dengan mudah dicari dan diakses secara detail dan cepat tanpa dibatasi oleh tempat dan waktu, Penelitian ini bertujuan untuk menganalisis apakah kualitas layanan berpengaruh terhadap kepuasan konsumen pengguna e-commerce Shopee. Kepuasan konsumen adalah suatu kewajiban bagi perusahaan untuk menjadi acuan penentu karir perusahaannya. Apa bila pelanggan tidak puas dengan layanan yang telah diberikan, Analisis penelitian ini menggunakan penelitian metode kuantitatif dan hasil data dihitung menggunakan SPPS. Hasil penelitian ini men unjukkan pengaruh kualitas layanan terhadap kepuasan konsumen sebesar $66,0 \%$, dan kualitas pelayanan memiliki hubungan yang kuat terhadap kepuasan konsumen dan bersifat positif.
\end{abstract}

Kata Kunci: e-commerce, kepuasan konsumen, kualitas pelayanan, Shopee

\section{Pendahuluan}

E-commerce merupakan bagian penting di dalam dunia bisnis. Seiring berjalannya waktu, perkembangan zaman berubah semakin cepat, teknologi mulai menghasilkan sesuatu yang mudah dan cepat untuk memenuhi kebutuhan masyarakat, salah satunya e-commerce. Perkembangan zaman yang semakin cepat dan modern inilah yang membuat gaya hidup kita semakin ingin serba mudah dan serba instan. Oleh karena

Tak pelak, setiap perusahaan pun berlomba-lomba untuk menciptakan dan menawakan berbagai keunggulan kepada konsumen dengan tujuan agar bisa terus 
menjalankan perusahaannya. Semakin banyak masyarakat yang berminat, maka semakin besar juga keuntungan yang didapatkan bagi perusahaan. Oleh karena itu, perusahaan harus memerhatikan perusahaan harus memerhatikan produk dan layanannya, termasuk penjualan melalui e-commerce.

Meningkatnya pertumbuhan e-commerce di Indonesia telah membuat banyak perusahaan mengubah cara menjalankan bisnisnya dengan mewujudkan atau beralih ke toko online meskipun telah mempunyai toko offline, ada pula perusahaan yang memang menciptakan toko khusus untuk online saja.

Salah satunya adalah Shopee, perusahaan yang ikut meramaikan industri ini. Shopee adalah situs e-commerce yang berada dibawah naungan SEA Group yang didirkan pada tahun 2009 oleh Forrest Li dan berkantor pusat di Singapura. (https://www.merdeka.com/uang/jatuh-bangun-bisnis-forrest-li-orang-terkayasingapura-pendiri-shopee-dan-garena.html, diakses pada tanggal 16 September 2020)

Shopee menawarkan beberapa keunggulan seperti barang cepat sampai, menawarkan diskon dan promo yang disenangi oleh pembeli, memiliki fitur pilihan terdekat hingga terjauh sehingga pembeli dapat mencari penjual yang terdekat ataupun terjauh dengan lokasi pembeli, adanya fasilitas gratis ongkos kirim dan tersedia berbagai produk dengan berbagai macam kategori. Di aplikasi Shopee juga telah dilengkapi fitur obrolan langsung atau live chat, social sharing, dan masih banyak lagi fitur lainnya yang diciptakan untuk membuat komunikasi antara penjual dan pembeli lebih mudah.

Namun di balik keunggulan yang ditawarkan juga terdapat beberapa kelemahan yang dimiliki oleh marketplace ini seperti slow respond, memberikan promo gratis ongkir dengan berbagai syarat dan ketentuan, beberapa tampilan iklan produk yang diunggah penjual kurang baik atau kurang menarik. Oleh karena itu penelitian ini dilakukan untuk meneliti kualitas pelayanan e-commerce Shopee terhadap kepuasan konsumen sebagai sarana berbelanja online.

Kualitas pelayanan ini diukur dengan menggunakan metode $e$-service quality yang terdapat tujuh dimensi yaitu Fulfillment, Efficient, Realibility, Responsiveness, Privacy, Compensation, dan Contact dan peneliti akan meneliti apakah kualitas pelayanan dengan tujuh dimensi tersebut berpengaruh terhadap kepuasan konsumen. Penelitian ini bertujuan untuk menganilisis apakah konsumen merasa puas dengan kualitas pelayanan yang tersedia di e-commerce Shopee dan menganalisis pengaruh dimensi kualitas pelayanan elektronik dengan menggunakan metode $e$-service quality yang terdapat tujuh dimensi tersebut.

\section{Metode Penelitian}

Metode yang dipakai dalam melakukan penelitian ini adalah metode penelitian kuantitatif. Menurut Sugiyono (2017), metode penelitian kuantitatif adalah metode yang berlandaskan filsafat positivisme yang mempunyai tujuan untuk melakukan penelitian terhadap populasi atau sampel tertentu.

Peneliti menggunakan penelitian metode kuantitatif ini untuk mendapatkan hasil dalam memahami fenomena dan gejala sosial yang sedang terjadi pada pengguna aplikasi Shopee. Peneliti menggunakan data yang telah dikumpulkan, menggunakan teori sebagai bahan penjelas, dan mencari hasil akhir dalam bentuk data.

Penelitian ini menggunakan metode penelitian yang bersifat deskriptif. Menurut Sugiyono (2015), penelitian deskriptif adalah penilitian yang ditujukan untuk mencari tahu nilai variabel (independent) tanpa adanya perbandingan dengan variabel 
lain. Metode deskriptif dalam penelitian ini ditujukan untuk mengetahui apa tanggapan konsumen yang menggunakan Shopee mengenai kualitas pelayanan yang diberikan.

Survey adalah metode penelitian yang digunakan di dalam penelitian ini. Sugiyono (2017) mendefinisikan penelitian survey adalah sebuah cara untuk mendapatkan data dari sampel yang diwakilkan dari populasi, sehingga ditemukan data-data yang berhubungan dan berdistribusi.

Populasi menurut Sugiyono (2017) adalah jumlah jiwa yang terdiri atas objek maupun subjek dan memiliki suatu karakter yang dinobatkan oleh peneliti sebagai perwakilan untuk kesimpulan. Populasi pada penelitian ini adalah pengguna Shopee. Populasi yang menggunakan aplikasi Shopee berjumlah lebih dari 50 juta unduhan pada tahun 2020 sesuai dengan data yang ada di App store dan Play store

Dikarenakan populasi pengguna Shopee mempunyai jumlah yang cukup besar, peneliti mengambil sampel sebagai perwakilan untuk memudahkan mengelola data penelitian. Menurut Sugiyono (2015), sampel adalah perwakilan kecil dari banyaknya jumlah populasi yang memiliki karakteristik yang dibutuhkan oleh peneliti. Sampel yang terdapat dalam penelitian ini merupakan masyarakat yang menggunakan Shopee dan berdomisili di Jakarta Barat.

Dalam penelitian ini, teknik non-probability sampling dengan purposive sampling menjadi acuan yang digunakan oleh peneliti. Purposive sampling adalah teknik yang digunakan dengan menentukan kriteria khusus terhadap sampel. Adapun kriteria utama sampel yaitu responden penelitian ini harus merupakan masyarakat Jakarta Barat, mempunyai dan menggunakan aplikasi Shopee.

Ukuran sampel yang layak menurut Roscoe adalah 30-500. Untuk menentukan jumlah sampel dalam penelitian, banyaknya responden yang digunakan untuk penelitian bergantung pada banyaknya jumlah indikator penelitian dikali 5 (Lestari, 2014). Dalam penelitian ini terdapat 18 indikator, maka 18 x $5=90$ responden yang akan menjadi jumlah sampel minimal dalam penelitian ini.

Purposive sampling menjadi pilihan peneliti dikarenakan tidak semua sampel memiliki kriteria yang penulis tentukan. Kriteria- kriteria tertentu yang harus dipenuhi oleh sampel-sampel penelitian adalah pengguna aplikasi Shopee dan berdomisili di Jakarta Barat.

Metode pengumpulan data yang digunakan peneliti adalah kuesioner dan skala pengukuran Likert. Menurut Sugiyono (2017), kuesioner adalah metode yang dilakukan untuk mendapatkan data dengan cara memberikan/menyebarkan/membagikan pertanyaan dan pernyataan secara tertulis maupun online kepada responden untuk dijawab. Pengukuran skala menurut Jogiyanto, 2004 (Nisfianmoor, 2011), adalah suatu alat ukur yang digunakan untuk membedakan individu ke dalam variabel yang digunakan di dalam penelitian.

Tipe skala ordinal menjadi skala pengukuran pada enelitian ini. Skala ordinal adalah skala dengan jumlah relatif katakteristik yang berbeda yang dimiliki oleh objek dan individu. Skala Likert digunakan untuk jawaban kusioner, yaitu sebagai berikut:

1. Bobot 1 diberikan untuk jawaban sangat rendah

2. Bobot 2 diberikan untuk jawaban rendah

3. Bobot 3 diberikan untuk jawaban netral

4. Bobot 4 diberikan untuk jawaban tinggi

5. Bobot 5 diberikan untuk jawaban sangat tinggi 


\section{Hasil Temuan dan Diskusi}

Dalam penelitian ini, terdapat 90 sampel responden. Seluruh responden yang mengisi kuesioner penelitian ini terdiri dari jenis kelamin pria sebanyak 39 orang $(43,3 \%)$ dan wanita sebanyak 51 orang $(56,7 \%)$. Hal ini menunjukkan bahwa responden yang berjenis kelamin laki-laki maupun perempuan masyarakat daerah Jakarta Barat pernah dana tau berbelanja melalui e-commerce Shopee. Dan sebanyak $34,4 \%$ berusia $18-21$ tahun, $53,5 \%$ berusia $22-25$ tahun, 3,3\% berusia $26-29$ tahun, dan $3,3 \%$ berusia diatas 29 tahun.

Uji Validitas, Pengujian validitas dalam penelitian ini dilakukan dengan menguji instrumen penelitian terhadap 90 responden masyarakat di daerah Jakarta Barat yang pernah berbelanja secara online melalu e-commerce Shopee. Pengujian dilakukan dengan menjadikan 0,2 (data diambil dari Tabel R) sebagai patokan terhadap kolom Corrected Item - Total Correlation.

Jika angka berada diatas 0,2 maka data dinyatakan valid, namun jika data dibawah nilai 0,2 maka dinyatakan tidak valid (gugur). Berikut adalah hasil uji validitas terhadap kualitas pelayanan $(\mathrm{X})$ dan kepuasan konsumen $(\mathrm{Y})$ : Berdasarkan hasil perhitungan melalui SPSS, disimpulkan bahwa terdapat 11 butir pernyataan dalam variabel X "Kualitas Pelayanan" mempunyai nilai $r$ hitung diatas 0,2, sehingga semua pernyataan dalam variabel $\mathrm{X}$ telah valid. Sama halnya dengan variabel $\mathrm{Y}$ "Kepuasan Konsumen" yang memiliki 7 butir pernyataan dan memiliki nilai $r$ hitung diatas 0,2, yang berarti semua pernyataan dalam variabel Y telah valid.

Uji reliabilitas, bertujuan untuk menguji dapat diandalkan atau tidak suatu pernyataan dalam kuesioner yang telah disebarkan. Suatu data disebut reliabel jika mempunyai nilai Cronbach's Alphanya diatas 0,6 . Berikut merupakan hasil uji reliabilitas dari variabel (X) Kualitas layanan dan variabel (Y) Kepuasan Konsumen: Berdasarkan hasil perhitungan data diatas, maka dapat dinyatakan bahwa seluruh pernyataan di dalam kuesioner telah reliabel karena nilai cronbach's alphanya di atas 0,6 .

Uji normalitas, dalam penelitian ini, peneliti menggunakan uji One Sample Kolmogorov Smirnov yang ada pada aplikasi SPSS. Uji normalitas ini bertujuan untuk mengetahui apakah sebuah data tersebut dikategorikan normal atau tidak. Hasil analisis data menunjukan bahwa terdapat nilai signifikansi sebesar 0,170 untuk variabel $\mathrm{X}$ dan 0,211 untuk variabel Y. Dari hasil tersebut dapat dinyatakan bahwa data telah berdistribusi secara normal karena memiliki nilai signifikansi X dan Y lebih besar dari 0,05

Uji koefisien korelasi, mempunyai fungsi untuk dapat mencari tahu apakah ada hubungan antara variabel bebas terhadap variabel terikat. Dengan bantuan program SPSS versi 25, peneliti melakukan perhitungan dan mendapatkan hasil sebagai berikut: Dari hasil perhitungan SPSS, diketahui nilai koefisien korelasi R sebesar 0,812 yang berada di antara interval 0,80 - 1000 (Tabel Interpretasi Koefisien Korelasi) artinya Kualitas Pelayanan dan Kepuasan Konsumen mempunyai hubungan yang sangat kuat.

Uji Koefisien determinasi bertujuan untuk mengetahui seberapa tingginya peran variabel bebas terhadap variabel terikat. Peneliti menggunakan program SPSS versi 25, dan melakukan perhitungan dan mendapatkan hasil sebagai berikut: Dari hasil perhitungan tabel 4.25, dapat diketahui tabel R Square sebesar 0.660 berarti nilai koefisien determinasi sebesar 66,0\% kepuasan konsumen dipengaruhi oleh kualitas pelayanan sementara sisanya 34,0\% (100\%-66,0\%) dipengaruhi oleh faktor lain.

Uji T, Hasil uji T bertujuan untuk apakah variabel X (Kualitas Pelayanan) 
memiliki pengaruh yang cukup signifikan terhadap variabel Y (Kepuasan Konsumen). Pengujian tersebut dapat dibuktikan dengan pembuktian sebagai berikut:

1. Ho: Sig $>\square$, kualitas pelayanan tidak mempunyai pengaruh terhadap kepuasan konsumen

2. Ha: Sig $<\square$, kualitas pelayanan mempunyai pengaruh terhadap kepuasan konsumen

Berdasarkan hasil analisis data diketahui bahwa nilai $\mathrm{t}=13,063$ dan tingkat signifikansi $=0,000<0,05$. Karena nilai $\mathrm{p}<0,05$, maka Ho ditolak dan Ha diterima, yang berarti kualitas pelayanan dan kepuasan konsumen memiliki pengaruh.

Uji regresi linear sederhana dilakukan untuk mengukur pengaruh variabel independen terhadap variabel dependen. Peneliti menggunakan bantuan SPSS versi 25.0 untuk mengetahui nilai konstanta variabel $\mathrm{X}$ dan $\mathrm{Y}$, dengan hasil sebagai berikut:

$$
\begin{gathered}
Y=a+b X \\
Y=5,472+0,510 X
\end{gathered}
$$

Deskripsi: $\mathrm{Y}=$ Kepuasan Konsumen dan $\mathrm{X}=$ Kualitas Pelayanan

Dapat diuraikan sebagai berikut:

1. Nilai Y (Kepuasan Konsumen) akan tetap sebesar 5,472 konstanta jika nilai $X$ (Kualitas Pelayanan) tidak mengalami perubahan, baik peningkatan maupun penurunan

2. Jika nilai $X$ (Kualitas Pelayanan) mengalami peningkatan nilai sebesar 1 satuan, maka nilai Y (Kepuasan Konsumen) akan mengalami peningkatan sebesar 0,510 menjadi 5,982

3. Nilai koefisien regresi positif (+), maka dengan itu dikatakan bahwa kualitas pelayanan memiliki pengaruh yang positif kepada kepuasan konsumen. Semakin tinggi suatu kualitas pelayanan maka kepuasan konsumen juga semakin meningkat. Begitu juga sebaliknya, semakin rendah suatu kualitas pelayanan, maka kepuasan konsumen juga semakin menurun.

\section{Simpulan}

Keseluruhan dari hasil penelitian ini menyatakan adanya pengaruh antara kualitas pelayanan yang diberikan oleh e-commerce Shopee terhadap kepuasan konsumen. Hal ini ditunjukkan dengan hipotesis dalam penelitian diterima, artinya terdapat pengaruh yang positif antara kualitas pelayanan terhadap kepuasan konsumen. Hal itu ditunjukkan pada hasil uji regresi linear sederhana yang dimana nilai koefisien regresi bernilai positif.

Dari pembahasan pada setiap tanggapan responden keseluruhan indikator dari variabel kualitas pelayanan dalam mempengaruhi kepuasan konsumen dinilai berpengaruh oleh masyarakat. Hasil dari uji koefisien korelasi, menunjukkan bahwa kualitas pelayanan dengan kepuasan konsumen mempunyai hubungan dengan nilai koefisien korelasi sebesar 0,812 yang berarti terdapat pengaruh yang sangat kuat.

Maka berdasarkan hasil penelitian dan pembahasan diatas, dapat disimpulkan bahwa kualitas pelayanan yang sangat kuat dapat mempengaruhi kepuasan konsumen sebab hasil dari koefisen korelasi dan analisis linear sederhana menyatakan bahwa kualitas pelayanan memiliki pengaruh yang sangat kuat terhadap kepuasan konsumen dan bersifat positif. 


\section{Ucapan Terima Kasih}

Dengan ini peneliti mengucapkan terima kasih kepada Fakultas Ilmu Komunikasi Tarumanagara serta seluruh pihak yang telah mendukung dan turut berkontribusi dalam penelitian ini.

\section{Daftar Pustaka}

Jatuh Bangun Bisnis Forrest Li, Orang Terkaya Singapura Pendiri Shopee dan Garena / merdeka.com. (n.d.). Retrieved September 16, 2020, from https://www.merdeka.com/uang/jatuh-bangun-bisnis-forrest-li-orang-terkayasingapura-pendiri-shopee-dan-garena.html

Lestari, R. A. (2014). Pengaruh Kepemimpinan Partisipatif Dan Komitmen Organisasi Terhadap Efektifitas Implementasi Rencana Stratejik Pada Madrasah Aliyah Di Kabupaten Sukabumi Jawa Barat.

Nisfianmoor, M. (2013). Pendekatan Statistika Modern: Aplikasi dengan Software SPSS dan EViews. Jakarta: Universitas Trisakti.

Sugiyono. (2015). Metode Penelitian Kuantitatif, Kualitatif, dan R\&D. Bandung: Alfabeta.

Sugiyono. (2017). Metode Penelitian Kuantitatif, Kualitatif, dan R\&D. Bandung: Alfabeta. 